\title{
EHMTI-0225. Peripheral nerve stimulation in drug-resistant cranial neuralgias
}

\author{
PE Bermejo ${ }^{1 *}, \mathrm{C}$ del Pozo ${ }^{2}$, E Parodi $^{2}, \mathrm{JM}$ Ahijado $^{2}, \mathrm{PR}^{2}$ \\ From 4th European Headache and Migraine Trust International Congress: EHMTIC 2014 \\ Copenhagen, Denmark. 18-21 September 2014
}

\section{Introduction}

Cranial neuralgias are distinct, treatable syndromes which comprise one of the possible causes of facial pain. Although some prophylactic medications and techniques have been proposed as treatments, there are still many refractory patients and other therapeutic options are warranted. Peripheral nerve stimulation (PNS) has been proposed as a promising therapy for these patients.

\section{Aim}

The aim of this study is to evaluate the efficacy and tolerability of PNS for the treatment of refractory cranial neuralgias.

\section{Methods}

Twelve patients ( 3 men, 9 women, average age $52.8 \pm$ 12.0) suffering from different drug-resistant cranial neuralgia were enrolled and implanted with a neurostimulation device. Five suffered from occipital neuralgia, 3 had postherpetic neuralgia and 4 had trigeminal neuralgia. The primary endpoint was the reduction in Analogical Visual Scale (AVS). Patient satisfaction, side effects and reasons for discontinuation were also studied. Significance level was set at $\mathrm{P}<0.05$.

\section{Results}

Pain severity according to the AVS was reduced from $9.0 \pm 0.9$ before PNS to $4.9 \pm 2.7$ after treatment initiation. $58 \%$ of treated patients were satisfied or very satisfied with the procedure. The most common adverse event was persistent implant site pain and three patients required to be explanted due to inefficacy. There were not differences between different subgroups.

${ }^{1}$ Neurology, Hospital Puerta de Hierro, Majadahonda, Spain

Full list of author information is available at the end of the article

\section{Conclusions}

PNS has been explored as a possible treatment option in selective drug-resistant cranial neuralgias and, according to our results, this technique may be effective, safe and well tolerated in treating them. More studies are warranted to confirm these results.

No conflict of interest.

\section{Authors' details}

${ }^{1}$ Neurology, Hospital Puerta de Hierro, Majadahonda, Spain. ${ }^{2}$ Pain Unit,

Hospital Puerta de Hierro, Majadahonda, Spain.

Published: 18 September 2014

doi:10.1186/1129-2377-15-S1-C6

Cite this article as: Bermejo et al:: EHMTI-0225. Peripheral nerve

stimulation in drug-resistant cranial neuralgias. The Journal of Headache and Pain 2014 15(Suppl 1):C6.

\section{SpringerOpen ${ }^{\odot}$}

(c) 2014 Bermejo et al; licensee Springer. This is an Open Access article distributed under the terms of the Creative Commons Attribution License (http://creativecommons.org/licenses/by/2.0), which permits unrestricted use, distribution, and reproduction in any medium, provided the original work is properly cited.
Submit your manuscript to a SpringerOpen ${ }^{\circ}$ journal and benefit from:

- Convenient online submission

- Rigorous peer review

- Immediate publication on acceptance

- Open access: articles freely available online

- High visibility within the field

Retaining the copyright to your article

Submit your next manuscript at $>$ springeropen.com 